FIU Law Review

Fall 2009

\title{
28 U.S.C. § 1782: The Most Powerful Discovery Weapon in the Hands of a Foreign Litigant
}

Luis A. Perez

Frank Cruz-Alvarez

Follow this and additional works at: https://ecollections.law.fiu.edu/lawreview

Part of the Other Law Commons

Online ISSN: 2643-7759

\section{Recommended Citation}

Luis A. Perez \& Frank Cruz-Alvarez, 28 U.S.C. § 1782: The Most Powerful Discovery Weapon in the Hands of a Foreign Litigant, 5 FIU L. Rev. 177 (2009).

DOI: https://dx.doi.org/10.25148/lawrev.5.1.12

This Article is brought to you for free and open access by eCollections. It has been accepted for inclusion in FIU Law Review by an authorized editor of eCollections. For more information, please contact lisdavis@fiu.edu. 


\title{
28 U.S.C. § 1782: The Most Powerful Discovery Weapon in the Hands of a Foreign Litigant
}

\author{
Luis A. Perez \\ Frank Cruz-Alvarez*
}

\section{INTRODUCTION}

Many U.S. and foreign practitioners are unfamiliar with "Assistance to Foreign and International Tribunals and to Litigants before such Tribunals," 28 U.S.C. § 1782 (“§ 1782”). ' Despite such unfamiliarity, § 1782 can be a foreign litigant's most powerful discovery weapon against a U.S. entity in a foreign proceeding. Section 1782 allows a foreign litigant to use U.S.-style discovery to extract evidence from a U.S. entity if the evidence is for use in a foreign proceeding. ${ }^{2}$ U.S. practitioners must familiarize themselves with $\S 1782$ because it can grant full U.S.-style discovery to a foreign litigant without any reciprocity in favor of the U.S. entity. ${ }^{3}$ In other words, $\S 1782$ can grant U.S.-style discovery to a foreign litigant but $\S 1782$ does not require that the foreign tribunal grant comparable foreign-style discovery to an opposing U.S. entity.

A foreign litigant now possesses a potent weapon against a U.S. entity in a foreign proceeding: access to the Federal Rules of Civil Procedure to extract discovery from a U.S. entity under the supervision of the U.S. federal courts. Practitioners must understand $\S 1782$ because it can lead to one-

\footnotetext{
* This article was originally presented at the Florida Bar International Law Section $8^{\text {th }}$ Annual International Law and Arbitration Conference on February 12, 2010, in Miami, Florida.

** Luis Perez is a shareholder in the Miami office of Akerman Senterfitt. His practice involves commercial litigation, general corporate work, international transactions, international arbitration, and international litigation. His undergraduate and law degrees are from Loyola University, New Orleans.

Frank Cruz-Alvarez is a partner in the Miami office of Shook, Hardy \& Bacon, LLP. He is a member of the firm's national products liability division and its international litigation and dispute resolution practice group. He received both his undergraduate and his law degree from the University of Florida with honors.

1 Assistance to Foreign and International Tribunals and to Litigants before such Tribunals, 28 U.S.C. § 1782(a) (1996).

2 See In re Schmitz, 259 F. Supp. 2d 294, 296 (S.D.N.Y. 2003) (noting that $\S 1782$ affords discovery of evidence in United States for use in foreign proceedings).

3 See In re Malev, 964 F.2d 97, 101 (2d Cir. 1992) (noting that Congress intended that $\S 1782$ would provide an avenue for discovery assistance to foreign tribunals whether or not reciprocal arrangements existed).
} 
sided discovery against U.S. entities. This article addresses the main provisions of $\S 1782$, its legislative history, cases interpreting $\S 1782$, and ramifications of $\S 1782$.

\section{MAIN PROVISIONS OF $§ 1782$}

Foreign litigants may use $\S 1782$ as a mechanism for obtaining U.S.style discovery to extract evidence from a U.S. entity under the supervision of a U.S. district court. ${ }^{4}$ The Eleventh Circuit, for example, affirmed a $\S$ 1782 discovery order granted to a Swiss litigant in Weber v. Finker. ${ }^{5}$ The Swiss litigant sought evidence from corporate shareholders residing in Florida, for use in a civil action in Cyprus. ${ }^{6}$ The Eleventh Circuit found no abuse of discretion in granting $\S 1782$ discovery assistance to the Swiss litigant. ${ }^{7}$ Thus a foreign litigant may use $\S 1782$ against a U.S. entity in a foreign proceeding, which may not provide for U.S.-style discovery. ${ }^{8}$

The current text of $\S 1782$ (a) reads as follows:

(a) The district court of the district in which a person resides or is found may order him to give his testimony or statement or to produce a document or other thing for use in a proceeding in a foreign or international tribunal, including criminal investigations conducted before formal accusation. The order may be issued pursuant to a letter rogatory issued, or request made, by a foreign or international tribunal or upon the application of any interested person ... . The order may prescribe the practice and procedure, which may be in whole or part the practice and procedure of the foreign country or the international tribunal, for taking the testimony or statement or producing the document or statement or producing the document or other thing. To the extent that the order does not prescribe otherwise, the testimony or statement shall be taken, and the document or other thing produced, in accordance with the Federal Rules of Civil Procedure.

\footnotetext{
4 Janis M. Meyer, Commentary on 28 U.S.C. $\$ 1782$ (LexisNexis 2009), available at LEXIS 28 US NITA 1782 ("Subsection (a) vests exclusive subject matter jurisdiction in the district court of the district in which 'a person' resides (or is found) to order 'him' to give testimony or to produce documentary evidence for use in the foreign tribunal.").

5 Weber v. Finker, 544 F.3d 1379, 1385 (11th Cir. 2009).

$6 \quad I d$. at 1381.

7 Id. at 1385.

8 See Intel Corp. v. Advanced Micro Devices, 542 U.S. 241, 247 (2004) (holding that $§ 1782$ contains no threshold requirement that evidence sought from federal district court would be discoverable under law governing the foreign proceeding).
} 
A person may not be compelled to give his testimony or to produce a document or other thing in violation of any legally applicable privilege. ${ }^{9}$

Section 1782 is so powerful because U.S.-style discovery is broader than discovery in most other countries. ${ }^{10}$ Latin American countries, for example, generally have more restrictive discovery rules than the U.S. So in a proceeding in a Latin American country involving a U.S. entity, a Latin American litigant could obtain broad U.S.-style discovery pursuant to $\S$ 1782. But the U.S. opponent may be limited by the restrictive Latin American discovery rules. The potential advantages of one-sided discovery encourage foreign litigants to apply for discovery assistance whenever they qualify under $\S 1782$. The difference between broad U.S.-style discovery and restrictive foreign-style discovery demonstrates the power of $\S 1782$ in a foreign litigant's hands.

\section{LEGISLATIVE HISTORY OF $§ 1782$}

Nearly 150 years of congressional effort produced the current version of $\S 1782$. $^{11}$ During this time, Congress progressed toward $\S 1782$ 's twin goals: (i) to provide efficient means of discovery assistance to foreign litigants and (ii) to encourage foreign countries to provide similar means of assistance to U.S. courts. ${ }^{12}$ The procedure for discovery assistance has changed over the years. Yet most changes promoted liberal access, with minimal restriction, to U.S. discovery assistance. Such changes include the following:

- In 1855, Congress first provided discovery assistance to foreign litigants when requests for assistance took the form of letters rogatory forwarded through diplomatic channels. ${ }^{13}$

- In 1863, Congress placed three limitations on discovery assistance to foreign litigants: the foreign suit for which the evidence sought had to (1) be "for the recovery of money or property," (2) be in a country "with which the United States are at peace," and (3) involve the foreign country as a participant or interested party. ${ }^{14}$

28 U.S.C. $\$ 1782$ (a).

10 See Societe Nationale Industrielle Aerospatiale v. S.D. Iowa, 482 U.S. 522, 542 (1987) (stating that it is well known that the scope of American discovery is often significantly broader than permitted in other jurisdictions).

11 Intel, 542 U.S. at 247.

12 Id. at 252.

13 Act of Mar. 2, 1855, ch. 140, § 2, 10 Stat. 630.

14 Act of Mar. 3, 1863, ch. 95, § 1, 12 Stat. 769-70. 
- In 1948, Congress broadened the scope of discovery assistance to foreign litigants. It eliminated the prior requirement that the foreign government be a party or have an interest in the foreign proceeding. It also permitted discovery assistance for any "judicial proceeding."

- In 1949, Congress broadened the scope of discovery assistance beyond a mere civil action. It replaced the term "civil action" with "judicial proceeding." 16

- In 1958, due to the growth of international commerce, Congress created the Commission on International Rules of Judicial Procedure ("the Commission"). The Commission investigated the discovery assistance procedures to make obtaining evidence "more readily ascertainable, efficient, economical, and expeditious.", "17

- In 1964, Congress adopted a complete revision of $\S 1782$, as recommended by the Commission. ${ }^{18}$ The current text of $\S 1782$ reflects the twin goals of the 1964 revision. ${ }^{19}$ The twin goals of $\S 1782$ are (i) to provide efficient means of discovery assistance to foreign litigants and (ii) to encourage foreign countries to provide similar means of assistance to U.S. courts. ${ }^{20}$

\section{INTERPRETATIONS OF $§ 1782$}

\section{A. Intel v. Advanced Micro Devices}

Intel v. Advanced Micro Devices ${ }^{21}$ is the seminal case interpreting $\S$ 1782. In that case, Advanced Micro Devices (AMD) sued its competitor Intel, for violating European antitrust laws. ${ }^{22}$ The case went before the Directorate-General for Competition of the Commission of the European Communities (the Directorate). ${ }^{23}$ The Directorate declined AMD's recommendation to seek discovery of documents, which Intel produced in a previous antitrust suit brought in an Alabama federal court. ${ }^{24}$ After being re-

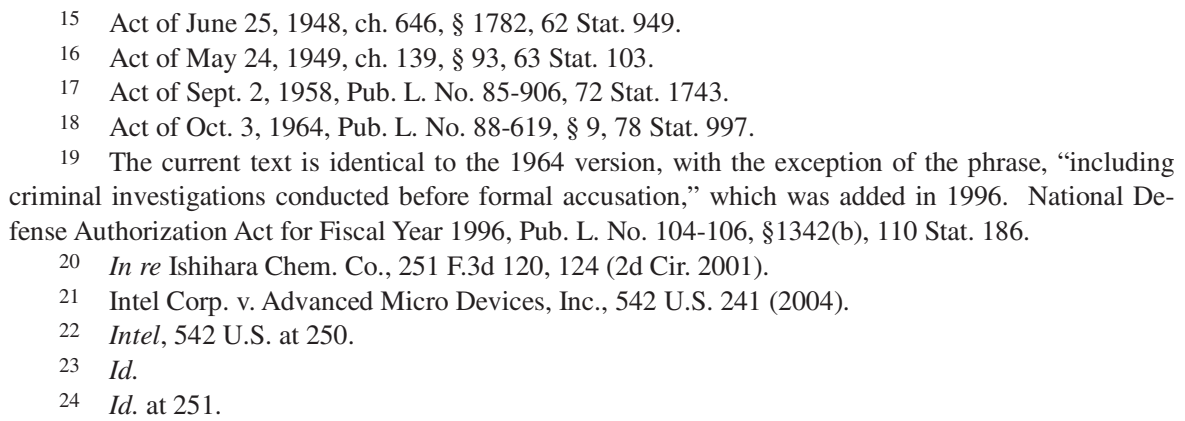


buffed by the Directorate, AMD then requested $\S 1782$ discovery assistance from the Northern District of California for production of Intel's documents. ${ }^{25}$ The northern district also denied AMD's request. ${ }^{26}$ The Ninth Circuit reversed and remanded. ${ }^{27}$ The U.S. Supreme Court granted certiorari. ${ }^{28}$

In Intel, the Supreme Court laid out the three statutory requirements of $\S 1782$ : (1) the person from whom discovery is sought resides or is found in the district court's jurisdiction, (2) the discovery is for use in a proceeding before a foreign tribunal, and (3) the application is made by a foreign or international tribunal or a foreign or international interested person. ${ }^{29}$

In Intel, the Supreme Court also noted that $\S 1782$ "authorizes, but does not require federal district courts to provide discovery assistance." ${ }^{\text {, }}$ In other words, satisfying $\S 1782$ 's three statutory requirements does not require a district court to grant a $\S 1782$ request; it merely allows a district court to do so. ${ }^{31}$ After satisfaction of $\S 1782$ 's three statutory requirements, a district court's determination to grant or deny a $\S 1782$ request may only be overturned for abuse of discretion. ${ }^{32}$

To guide a district court's discretion, the Supreme Court listed various factors for a court to consider when determining whether to grant a $\S 1782$ request: (a) the nature and character of the foreign tribunal; ${ }^{33}$ (b) whether a party or a non-party is requesting the evidence, because non-parties have a greater need for $\S 1782$ assistance, $^{34}$ (c) whether the requesting party is attempting to circumvent foreign discovery restrictions or policies; ${ }^{35}$ and (d) whether the request is unduly intrusive or burdensome. ${ }^{36}$

Given Intel's interpretation of $\S 1782$, whether a court should grant discovery assistance to a foreign litigant turns on a two-step analysis: (I) whether a foreign litigant satisfies $\S 1782$ 's statutory requirements and (II) if so, whether the court should grant a $\S 1782$ request, based on the discretionary factors.

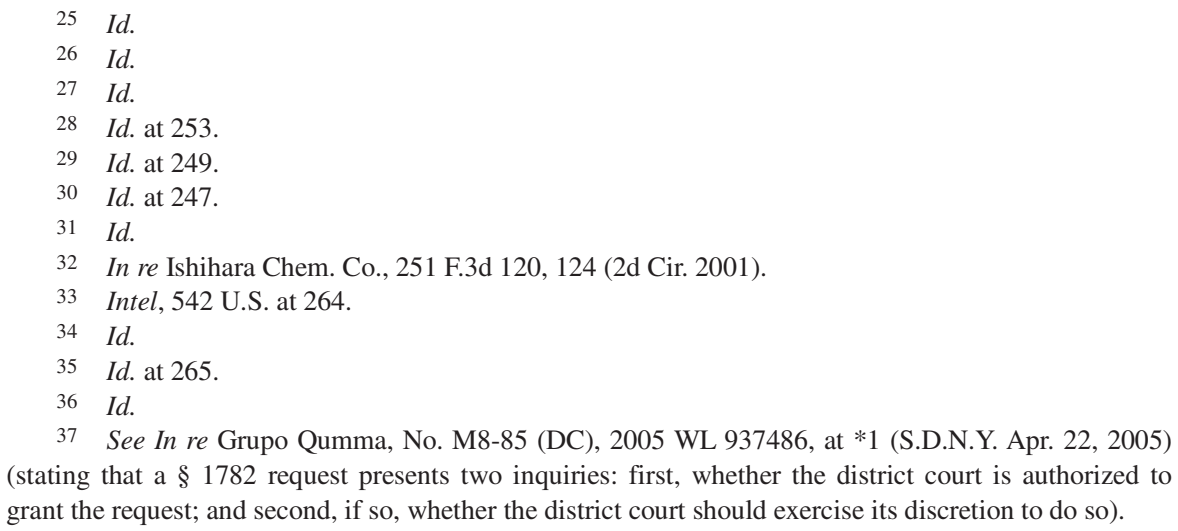


The Intel Court broadly construed terms such as "tribunal", and "interested person" as used within $\S 17822^{39}$ The Court included the Directorate in $\S 1782$ 's term "tribunal" because it "acted as a first-instance decision maker." Regarding the term "interested person," the Court rejected Intel's argument that the term only included litigants, foreign sovereigns and designated agents of those sovereigns. ${ }^{41}$ Instead, the Court included AMD within the term "interested person" because it possessed a reasonable interest in obtaining judicial assistance. ${ }^{42}$ Thus, the Intel Court expanded the types of parties, tribunal bodies, and proceedings included within the scope of $\S 1782$.

The Intel Court also rejected categorical limitations on $\S 1782$ discovery assistance. ${ }^{43}$ A district court should determine a $\S 1782$ request based on the discretionary factors, rather than relying on categorical limitations. ${ }^{44}$ For example, the Intel Court rejected a foreign-discoverability categorical limitation. $^{45}$ This foreign-discoverability requirement would preclude $\S$ 1782 discovery assistance where the sought-after evidence was not discoverable under the foreign jurisdiction's discovery rules. ${ }^{46}$ The Intel Court rejected this categorical limitation because nothing in the text, plain meaning, or legislative history of $\S 1782$ imposes such a foreign-discoverability requirement on a district court's discretion to grant discovery assistance. Thus by broadly construing the terms of the statute and rejecting categorical limitations on its use, Intel interpreted $\S 1782$ to advance the statute's twin goals.

\section{B. Courts Broadly Construe $§ 1782$ to Further the Statute's Twin Goals}

\section{Courts Rejected the Exhaustion of Remedies Requirement}

The Second Circuit rejected the argument that $\S 1782$ imposed an exhaustion of available remedies requirement in In re Malev. ${ }^{48}$ In that case, a Hungarian airline applied for $\S 1782$ discovery assistance without first

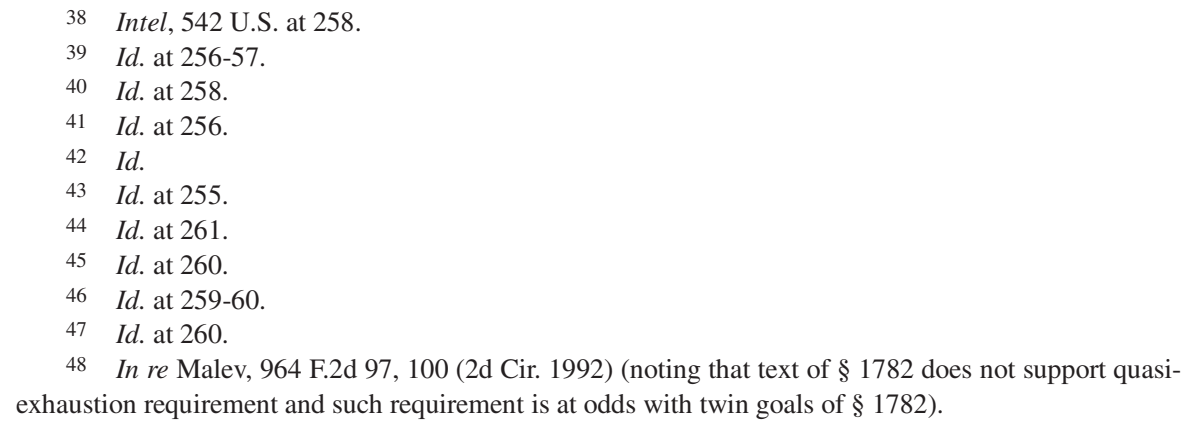


seeking available Hungarian discovery. ${ }^{49}$ The Hungarian airline sought discovery from a U.S. aircraft manufacturer for use in a Hungarian proceeding. ${ }^{50}$

The three-judge panel with Judge Feinberg dissenting, ruled that a foreign litigant need not exhaust other available discovery options before applying for $\S 1782$ discovery assistance. ${ }^{51}$ Nothing in the text or legislative history supports a quasi-exhaustion requirement. ${ }^{52}$ Also, such a quasiexhaustion requirement is at odds with the twin goals of $\S 1782$.

Judge Feinberg dissented in the ruling. ${ }^{54}$ Judge Feinberg asserted that the law generally requires exhaustion of remedies and that $\S 1782$ appropriately requires exhaustion of remedies because the federal courts are already heavily burdened. ${ }^{55}$ Nonetheless, the Second Circuit rejected a quasiexhaustion requirement on $\S 1782$ discovery assistance because such a requirement lacked support from the statute's text or legislative history and such a requirement is at odds with $\S 1782$ 's twin goals.

\section{Courts Include Arbitral Proceedings Within the Scope of $\S 1782$}

As previously mentioned, $\S 1782$ requires that the requested discovery is for use in a proceeding before a "foreign tribunal.",56 Currently, arbitral proceedings fall within $\S 1782$ 's "foreign tribunal" term because the Intel Court approvingly quoted a law review article, which included arbitral tribunals within the term "foreign tribunal.", After Intel, two recent decisions interpreted Intel to include arbitral proceedings within the term "foreign tribunal" for $\S 1782$ purposes. ${ }^{58}$ But before Intel, the Second and Fifth Circuits excluded arbitral proceedings from the scope of $\S 1782$.

Before Intel, the Second and Fifth Circuits held that $\S 1782$ does not include arbitral proceedings. ${ }^{59}$ The Second Circuit excluded private arbitration because the efficiency characteristics of arbitration are at odds with the full scale discovery made possible by $\S 1782 .^{60}$ The Fifth Circuit held that

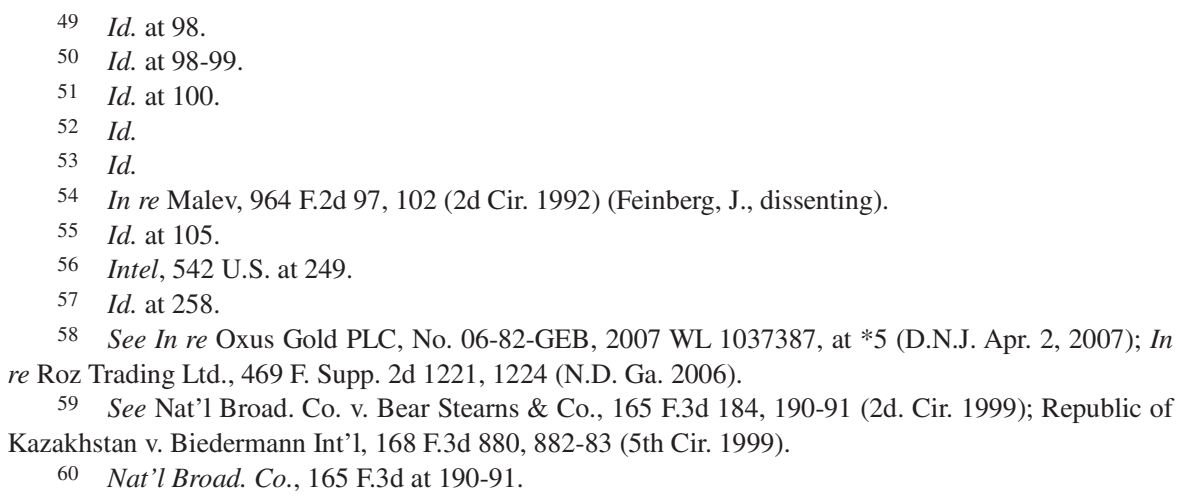


the term "foreign tribunal" was not meant to include every conceivable adjudicative body and that $\S 1782$ 's history lacked any mention of arbitration tribunals. ${ }^{61}$ Thus, the pre-Intel decisions excluded "arbitral proceedings" from the scope of $\S 1782$.

After Intel, two recent decisions interpreted Intel to include arbitral proceedings within the scope of $\S 1782 .^{62}$ The District of New Jersey upheld a magistrate judge's conclusion that an arbitration panel constituted a "foreign tribunal" because it was not clearly erroneous. ${ }^{63}$ The Northern District of Georgia noted that although Intel did not expressly hold arbitral bodies to be "foreign tribunals," it approvingly quoted language that included "arbitral tribunals" within the meaning of $\S 1782 .^{64}$ Thus, the postIntel decisions included "arbitral proceedings" within the scope of $\S 1782$.

The post-Intel decisions, including arbitral proceedings, are in stark contrast to the pre-Intel decisions, which excluded arbitral proceedings. ${ }^{65}$ Based on its interpretation of Intel, the post-Intel decisions declined to follow the pre-Intel decisions. Inclusion of arbitral proceedings expands the scope of $\S 1782$ discovery assistance. Thus courts continue to broadly interpret $\S 1782$ to further the section's twin goals of efficient means of discovery assistance for a foreign litigant and encouraging foreign jurisdictions to adopt similar means.

\section{Many Questions Still Surround $§ 1782$ and its Current Use}

Many questions remain concerning $\S 1782$ : (i) whether $\S 1782$ contains an implied geographical limitation that precludes discovery of evidence located outside the U.S. and (ii) whether use of $\S 1782$ subjects a foreign litigant to U.S. personal jurisdiction, making it prone to a U.S. entity's counterclaim. Congress or the courts should answer these questions in a manner that advances the twin goals of $\S 1782$ while also protecting the interests of U.S. entities embroiled in foreign proceedings. If these questions remain unanswered for too long, abuse of $\S 1782$ is likely to occur.

\section{Whether $\S 1782$ Imposes a Geographical Limitation on Discovery}

Disagreement exists over whether $\S 1782$ imposes an implicit geographical limitation that bars production of evidence located beyond U.S. borders. The Intel Court failed to address this ambiguity. In 2006, Judge

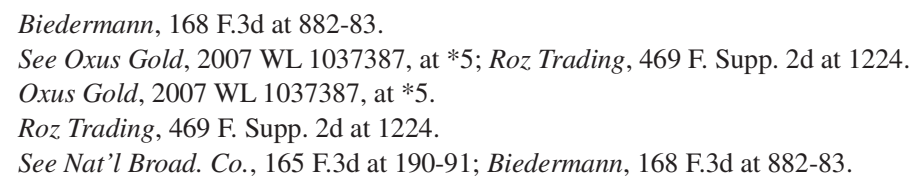


Jones writing for the Southern District of New York rejected a geographical limitation on $\S 1782$ in In re Gemeinschaftspraxis. ${ }^{66}$ In that case, a German litigant filed a $\S 1782$ request for documents from a New York City consulting firm, for use in a German proceeding. ${ }^{67}$ The documents were located in Germany. ${ }^{68}$ Nonetheless, Judge Jones relied on Intel's broad interpretation of $\S 1782$ and ordered production of the documents located in Germany. ${ }^{69}$

Yet in 2007, Judge Rakoff, writing for the same court in In re Godfrey, ${ }^{70}$ disagreed with Judge Jones. ${ }^{71}$ Judge Rakoff rejected the proposition that Intel allows a foreign litigant to use $\S 1782$ to discover evidence located abroad. $^{72}$ Thus Judge Rakoff held that $\S 1782$ discovery assistance was inappropriate for documents located in Russia, based on the reasoning that $\S 1782$ implicitly contained a geographical limitation. ${ }^{73}$ Otherwise, the U.S. district courts might become a clearing house for evidence located all over the world for use in tribunals all over the world. ${ }^{74}$

Moreover, Gemeinschaftspraxis's rejection of a geographical limitation might lead to abuse of $\S 1782$ discovery assistance. For example, a Brazilian tribunal might deny a Brazilian litigant's request for discovery of a U.S. entity's documents located in Brazil. Regardless, the Brazilian litigant may use $\S 1782$ to gain the documents located in Brazil, according to Gemeinschaftspraxis, even though the Brazilian tribunal has already denied its discovery and the documents are located in Brazil. Thus, a foreign litigant can use $\S 1782$ to bypass the discovery rules of a foreign jurisdiction. Unfortunately, Intel did not address the issue of a geographical limitation on $\S 1782$, so judges and practitioners are left with an unanswered question.

2. Whether $\S 1782$ Subjects a Foreign Litigant to U.S. Personal Jurisdiction

No court has addressed whether use of $\S 1782$ subjects a foreign litigant to U.S. personal jurisdiction, making it prone to a U.S. entity's counterclaim. A U.S. entity can argue that a foreign litigant has subjected itself

66 In re Gemeinschaftspraxis, No. Civ. M19-88 (BSJ), 2006 WL 3844464, at *8 (S.D.N.Y. Dec. 29, 2006).

67 Id. at $* 1$.

Id.

Id. at $* 8$.

In re Godfrey, 526 F. Supp. $2 \mathrm{~d} 417$ (S.D.N.Y. 2007).

Id. at 423.

Id. at 424 .

Id. at 423 .

74 Id. ("Evidence located in Spain is obtained through proceedings in Spain, evidence in Great Britain is obtained through proceedings in Great Britain, and evidence in the United States is obtained through proceedings in the United States."). 
to U.S. personal jurisdiction, because commencement of an ancillary action like a $\S 1782$ application may constitute sufficient minimum contact with a forum state. That said, subjecting a foreign litigant to U.S. personal jurisdiction might run counter to $\S 1782$ 's twin goals of efficient means to discovery assistance and encouraging foreign jurisdictions to adopt similar means.

There is a strong policy argument against subjecting a foreign litigant to U.S. jurisdiction. Subjecting a foreign litigant to U.S. jurisdiction is seemingly at odds with Congress's twin goals of $\S 1782$ : to provide efficient means of discovery assistance and to encourage foreign jurisdictions to provide similar discovery assistance. Subjecting a foreign litigant to U.S. jurisdiction complicates the means of discovery assistance to a foreign litigant. Also, the prospect of its constituents being hailed into a U.S. district court presumably deters a foreign jurisdiction from providing similar discovery assistance. Thus a U.S. district court would be reluctant to subject a foreign litigant to U.S. jurisdiction because such a result runs counter to the statute's twin goals and congressional intent.

Potentially, a U.S. entity can counterclaim in a U.S. district court against a foreign litigant who exercises $\S 1782$. To do so, however, a U.S. entity must prove that personal jurisdiction exists over the foreign opponent. $^{75}$ In other words, a U.S. entity must demonstrate a foreign litigant's minimum contacts with the forum state.

In a situation analogous to a foreign litigant's use of $\S 1782$, the Ninth Circuit held that a French agency's contacts with the state of California justified personal jurisdiction in Yahoo! Inc. v. La Ligue Contre le Racisme et L'antisemitism. ${ }^{76}$ In that case, the French agency obtained two French court orders directing Yahoo! to take all necessary steps to dissuade and render impossible any access to any website or service that sympathizes or apologizes for Nazism. ${ }^{77}$ Yahoo! sought declaratory judgment against the French agency in the Northern District of California to render the French orders unenforceable. ${ }^{78}$ The French agency argued that the Court lacked personal jurisdiction over it. ${ }^{79}$

The French agency's three contacts with the state of California were (i) sending a letter demanding that Yahoo! alter its behavior in California to

\footnotetext{
75 Technical Witts, Inc. v. Skynet Elec. Co., No. CV 04-2025-PHX-MHM, 2007 WL 809856, at *2 (D. Ariz. Mar. 12, 2007).

76 Yahoo! Inc. v. La Ligue Contre le Racisme et L'antisemitism, 433 F.3d 1199, 1211 (9th Cir.

77 Id. at 1202 .

78 Id. at 1205.

79 Id.
} 2006). 
comply with French law; ${ }^{80}$ (ii) serving process on Yahoo! in California; ${ }^{81}$ and (iii) obtaining two French court orders directing Yahoo! to take actions in California, under threat of penalty. ${ }^{82}$ The Ninth Circuit found no basis for jurisdiction in the first two contacts, taken by themselves. ${ }^{83}$ The Court, however, found a basis for jurisdiction in the third contact, the French court orders. $^{84}$

The Ninth Circuit concluded that the orders subjected the French agency to U.S. personal jurisdiction, because they directed Yahoo! to perform significant acts in California. ${ }^{85}$ The French orders directed Yahoo! to change its California-based servers to comply with French law. ${ }^{86}$ By analogy, a $\S 1782$ discovery order would direct a U.S. entity to produce documents and other evidence, while the Yahoo! court orders directed a U.S. company to change its website servers. Presumably, production of evidence constitutes a significant act similar to changing a website server. Thus, a U.S. district court might subject a foreign litigant to jurisdiction for using $\S$ 1782 .

That said, district courts should not subject a foreign litigant to full U.S. jurisdiction. Such a result does not comport with $\S 1782$ 's twin goals of efficient means of discovery assistance and encouraging foreign jurisdictions to adopt similar means. Considering the broad judicial interpretations of $\S 1782$, courts should reject a result that is at odds with $\S 1782$ 's twin goals. Therefore, courts should not subject a foreign litigant to U.S. jurisdiction for mere use of $\S 1782$. This issue remains undecided, however, and ample room for arguing both sides of the issue still exists.

\section{THE RAMIFICATIONS OF $§ 1782$}

\section{A. How can $\S 1782$ Place U.S. Entities at a Disadvantage?}

Courts interpreting $\S 1782$ have given foreign litigants a vastly different set of rights than U.S. entities. Foreign litigants must only meet the three statutory requirements and satisfy a court's discretion to gain the full force of discovery under the Federal Rules of Civil Procedure. The text of $\S 1782$ does not afford a U.S. litigant any reciprocity. In other words, the foreign jurisdiction's discovery rules may restrict a U.S. litigant's discovery,

\footnotetext{
Id. at 1208.

Id. at 1209.

Id.

Id. at 1208.

Id.

Id. at 1209.

Id.
} 
while a foreign litigant may exercise broad U.S.-style discovery pursuant to $\S 1782$. This may result in one-sided discovery in a foreign litigant's favor. Thus, the rights of a foreign litigant differ from the rights of a U.S. litigant.

Judicial interpretations of $\S 1782$ have also placed U.S. litigants at a disadvantage to foreign litigants. The Intel Court held that $\S 1782$ does not require foreign-discoverability; meaning that the sought-after evidence need not be discoverable under the foreign jurisdiction's discovery rules. ${ }^{87}$ The Second Circuit further held that $\S 1782$ does not require a foreign court to reciprocate with similar discovery assistance in favor of a U.S. litigant. ${ }^{88}$ In fact, the Northern District of California asserted that a court should disregard the lack of a reciprocal treaty when determining whether to grant a $\S$ 1782 request. $^{89}$ Instead, a district court should only consider lack of reciprocity if a foreign jurisdiction has expressly refused a U.S. request for similar discovery assistance. ${ }^{90}$ These interpretations of $\S 1782$ place a U.S. entity at a disadvantage when compared to a foreign litigant.

\section{B. How can 1782 lead to Abuse or Misuse?}

A U.S. practitioner's greatest concern is that $\S 1782$ will encourage unfair play and one-sided discovery. Without a reciprocity requirement, a foreign-discoverability requirement, or other limitations on $\S 1782$ 's availability to a foreign litigant, one-sided discovery is possible and likely in a foreign proceeding. For example, a foreign litigant may request discovery from a U.S. entity pursuant to contractually agreed-upon discovery rules, and the request may be denied. Even so, the foreign litigant may use $\S$ 1782 to obtain the denied discovery under the supervision of a U.S. district court. Thus, the minimal restrictions and broad interpretations of $\S 1782$ encourage a foreign litigant to pursue one-sided discovery.

\footnotetext{
87 Intel, 542 U.S. at 260-61 (holding that $\S 1782$ does not impose a blanket foreigndiscoverability rule on discovery assistance to foreign tribunals).

88 See In re Malev, 964 F.2d 97, 101 (2d Cir. 1992) (holding that Congress intended that $\S 1782$ would provide an avenue for discovery assistance to foreign tribunals whether or not reciprocal arrangements existed).

89 In re Request for Judicial Assistance from Seoul Dist. Criminal Court, 428 F. Supp. 109, 112 (N.D. Cal. 1977) (noting that because there was no evidence that Korea had refused to provide similar assistance to U.S. courts when requested, accordingly, the district court should disregard the lack of reciprocity).
}

$90 \quad I d$. 
C. How Can U.S. Entities Protect Themselves from $\S 1782$ ?

\section{Preempt and Preclude a Foreign Litigant's Access to $\S 1782$}

U.S. entities can protect themselves from the disadvantages of $\S 1782$ by preempting its use. Parties must be aware of $\S 1782$ and its relevant case law to preempt it. When contracting with a foreign party, a U.S. entity should preclude $\S 1782$ discovery in its arbitration or litigation clause. A U.S. entity should use its contract with a foreign entity to even out the discovery disparity imposed by $\S 1782$. Thus, a U.S. entity can discount the risk of one-sided discovery by preemptively contracting out the disadvantages and precluding the exercise of $\S 1782$. Enforcement of such a preemptive clause is another undecided issue. Sound arguments can be made for both enforceability and unenforceability. Despite the ambiguity, a prudent U.S. party should include a preemptive clause for the chance to preclude $\S 1782$ 's disadvantages. Of course, a U.S. entity that lacks a contract with a foreign litigant cannot use this protective measure.

\section{Persuade a U.S. District Court to Deny a $§ 1782$ Request}

A U.S. entity can also protect itself by persuading a U.S. district court to deny the $\S 1782$ request for discovery assistance. A U.S. entity is free to expose the one-sided discovery advantage that a foreign litigant is requesting. In exercising its discretion, a court may consider the "nature" of the proceedings. $^{91}$ If a foreign litigant seeks to manipulate or circumvent the nature of those proceedings, a court is more likely to deny the $\S 1782$ request. Section 1782's disadvantages, in fact, may help a U.S. entity to persuade a court to deny the requested discovery assistance. Thus, a U.S. entity can protect itself by persuading a court to deny a $\S 1782$ request.

\section{Persuade a U.S. District Court to Condition a $\S 1782$ Discovery Order}

A U.S. entity can also protect itself by persuading a U.S. district court to grant a $\S 1782$ discovery order only on the condition that its foreign opponent provide reciprocal discovery for the U.S. entity. The Second Circuit directed a district court to do so in Euromepa S.A. v. R. Esmerian, Inc. ${ }^{92}$ In

91 In re Godfrey, 526 F. Supp. 2 d at 419 (stating that courts may consider the nature of the foreign tribunal, the character of the proceedings underway abroad, and the receptivity of the foreign government or the court or agency abroad to U.S. federal-court discovery assistance).

92 Euromepa S.A. v. R. Esmerian Inc., 51 F.3d 1095, 1101 (2d Cir. 1995) (“[W]e think that it is far preferable for a district court to reconcile whatever misgivings it may have about the impact of its 
that case, a French company applied for $\S 1782$ discovery assistance in the Southern District of New York. ${ }^{93}$ The French company sought discovery from a New York jeweler for use in a French proceeding. ${ }^{94}$ The Southern District denied the $\S 1782$ application. ${ }^{95}$ The Second Circuit reversed because $\S 1782$ 's underlying twin goals should generally prompt district courts to provide some form of discovery assistance. ${ }^{96}$ The lower court partially based its denial on concerns of unfair play. ${ }^{97}$ If granted, the French company would obtain discovery against the New York jeweler in the U.S., but the New York jeweler would be unable to obtain analogous discovery in France. $^{98}$ In response to unfair play concerns, the Second Circuit encouraged courts to grant narrowly tailored $\S 1782$ discovery orders, conditioned on reciprocal discovery in favor of the U.S. entity. ${ }^{99}$ Although the text of $\S$ 1782 does not require reciprocity, a court in its discretion may condition a $\S$ 1782 discovery order on reciprocity. ${ }^{100}$ Thus, a U.S. entity can protect itself by persuading a U.S. district court to grant only $\S 1782$ discovery orders conditioned on reciprocity. ${ }^{101}$

\section{Postpone Production of $\S 1782$ Evidence}

A U.S. entity can also protect itself by postponing production of evidence sought by a foreign litigant's $\S 1782$ request. A U.S. entity should never concede to a $\S 1782$ request before a district court grants it. Regardless of how imminently successful the $\S 1782$ request may appear, postponing production of evidence may be a small victory in the totality of the foreign proceeding. A foreign tribunal might suppress untimely evidence for missing deadlines. Circumstantial changes in the foreign proceeding may render the discovered evidence moot or irrelevant. So an unsuccessful challenge to a $\S 1782$ request may result in strategic advantages for a U.S. entity, even if the $\S 1782$ request is granted and the evidence is eventually produced at a later date. Thus, postponing production of evidence may strategically protect a U.S. entity from $\S 1782$ 's discovery disadvantages.

\footnotetext{
participation in the foreign litigation by issuing a closely tailored discovery order rather than by simply denying relief outright.").

93 Id. at 1096.

$94 \quad I d$. at 1097.

95 Id.

96 Id. at 1102.

$97 \quad I d$.

$98 \quad I d$.

$99 \quad I d$.

100 In re Edelman, 295 F.3d 171, 181 (2d Cir. 2002) (noting that district courts should consider procedural parity of parties to foreign litigation when deciding to issue a $\S 1782$ discovery order).

101 See In re Ishihara Chem. Co., 251 F.3d 120, 127 n.5 (2d Cir. 2001) (expressing concern over $\S$ 1782 discovery orders that lead to unbalanced discovery between parties to foreign litigation).
} 
5. Research Foreign Jurisdictional Precedent Regarding $§ 1782$

A U.S. entity can protect itself with foreign precedent where the foreign jurisdiction specifically refuses $\S 1782$ discovery assistance. A U.S. entity should carefully research foreign cases, which demonstrate reticence toward U.S. discovery assistance. Any specific precedent refusing discovery assistance offered from a U.S. court might persuade a district court to deny a $\S 1782$ request. $^{102}$ The Second Circuit, for example, denied a $\S 1782$ request in Schmitz v. Bernstein Liebhard \& Lifshitz, LLP because the German government requested that U.S. federal courts deny the $\S 1782$ request. $^{103}$ The German government did so, because granting the $\S 1782$ request would have jeopardized an ongoing German criminal investigation. ${ }^{104}$ Thus, foreign cases specifically refusing $§ 1782$ assistance might persuade a district court, in its sound discretion, to deny a $\S 1782$ request. As a result, a U.S. entity can protect itself with foreign precedent, which specifically refuses discovery assistance offered by a U.S. court.

\section{CONCLUSION}

Section 1782 is a powerful weapon in a foreign litigant's arsenal against a U.S. entity. A foreign litigant may use $\S 1782$ to extract discovery from a U.S. entity without reciprocal discovery for the U.S. entity. A district court may grant $\S 1782$ discovery assistance if (1) the person from whom discovery is sought resides or is found in the district court's jurisdiction, (2) the discovery is for use in a proceeding before a foreign tribunal, (3) the request is made by a foreign tribunal or interested person, and (4) the district court, in its discretion, grants the requested discovery. ${ }^{105}$ Courts have broadly interpreted $\S 1782$ and rejected most limitations on its use, which is why $\S 1782$ is so powerful in the hands of a foreign litigant. Yet many U.S. and foreign practitioners remain unfamiliar with $§ 1782$.

A U.S. practitioner must understand $\S 1782$ 's harsh reality to effectively represent U.S. clients. The lack of a foreign discoverability or reciprocity requirement leaves U.S. entities at a disadvantage. Also, § 1782's current interpretations leave many ambiguities such as the geographical limitation and whether use of $\S 1782$ subjects a foreign litigant to U.S. personal jurisdiction. Congress or the courts should answer these questions to advance the goals of $\S 1782$ while also protecting the interests of U.S. entities embroiled in foreign proceedings. But for now, a U.S. practitioner must un-

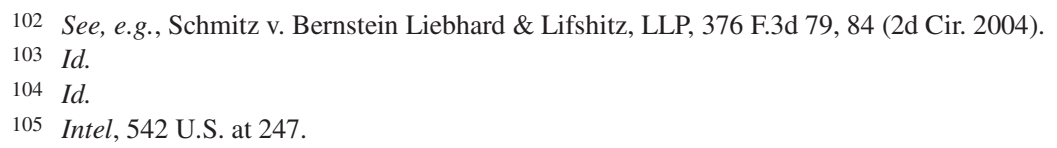


derstand "Assistance to Foreign and International Tribunals and to Litigants before such Tribunals," 28 U.S.C. $§ 1782$ and its disadvantages, in order to effectively represent U.S. clients. 